Визначено фактори, які виникають під час дугового розряду, та визначено можливість використання для прискорення роботи захисту від дугового замикання. Це дає можливість створення комбінованого пристрою для точного визначення місия дугового розряду. Зокрема, може бути розширено спектр чутливості оптичного датчика за рахунок використання ультрафіолетового випромінювання без його заміни.

Розглянуто можливість прискорення спрацьовування захисту від дугового замикання за рахунок відмови від його блокування з релейними схемами максимального струмового захисту та зменшення впливу сонячного випромінювання на роботу 3 ДЗ (захисту від дугового замикання).

Обтрунтовано можлливість розроблення більи досконалого пристрою для захисту від дугових замикань, який дозволяє розширити спектр оптичного датчика в область ультрафіолетового випромінювання.

Запропоновано вирішення задачі підвищення чутливості захисту від дугового замикання. Це можливо шляхом перетворення ультрафіолетового випромінювання у видиму частину оптичного спектру, що дозволить розширити спектр чутливості оптичного датчика в область ультрафіолетового випромінюван ня і відповідно дасть можливість підвищити його чутливість. Це пов'язано з тим, що 70 \% випромінювання дугового розряду припадає на область ультрафіолету i тільки по $15 \%$ на видимий та інфрачервоний спектр оптичного випромінювання.

Отримані результати дають підстави стверджувати щодо можливості втілення у реальне промислове виробництво пристрою комбінованого захисту для визначення місия дугових замикань, а також розширення спектральної чутливості оптичних датчиків. Також розроблено комбінований пристрій для визначення місия дугового розряду за рахунок використання ультразвукової системи. Відомі розробки, які присвячені визначенню місия дугового розряду иляхом порівняння інтенсивності сигналу від спалаху на обох кіниях десятиметрового світлопроводу, відрізняються тим, що максимальна різниия часу надходження сигналів від точки спалаху до датчиків на кіниях світлопроводу становить 5нс. Це дуже низъкий часовий рівень у порівнянні довжини світлопроводу з ивиджістю світла 300000 км/c.

Запропонована в даній роботі система, у якій для визначення місия дугового розряду використовується швидкість звуку, яка досягає 342 м/с, значно спрощує пристрій вимірювання часу для визначення місия короткого замикання та підвищуе точність вимірювання часу на три порядки (103)

Ключові слова: захисту від дугового замикання, чутливість захисту, спектр випромінювання, перетворення ультрафіолетового випромінювання $\square$

口
UDC 62-768.3

DOI: $10.15587 / 1729-4061.2018 .134016$

\section{DESIGNING A COMBINED} DEVICE FOR DETERMINING THE PLACE OF ARC DISCHARGE

R. Parkhomenko Senior Lecturer* E-mail: parchom@i.ua

O. An isk ov

Assistant*

Y. Ts i bu levsk y

$\mathrm{PhD}$, Associate professor

LLC "Rudpromgeofizika"

Kryvbasivska str., 54, Kryvyi Rih, Ukraine, 50000

O. Meln i k

$\mathrm{PhD}$, Associate professor*

O. Shchokina

Senior Lecturer*

O. Kharitonov

Lecturer

Ukrainian Polytechnic College

Karla Marksa ave., 66, Kryvyi Rih, Ukraine, 50000

O. Kryve n k o

$\mathrm{PhD}$, Associate Professor, Senior Researcher

Research Institute of Labor Safety and Ecology in Mining and Metallurgical Industry

Pershotravneva str., 12, Kryvyi Rih, Ukraine, 50000

O. O m e I c h e n k o

$\mathrm{PhD}$

Department of general engineering disciplinesan dequipment Donetsk National University of Economics and Trade named after Mikhail Tugan-Baranovsky

Tramvayna str., 16, Kryvyi Rih, Ukraine, 50005

V. Chorna

$\mathrm{PhD}$

Department of systems of

power consumption and energy management

Kremenchuk Mykhailo Ostrohradskyi National University

Pershotravneva str., 20, Kremenchuk, Ukraine, 39600

S. T s virkun

$\mathrm{PhD}$

Department of Radiotechnics and Electromechanics Krivorizky College of the National Aviation University Tupolieva str, 1, Kryvyi Rih, Ukraine, 50045

*Department of power supply and energy management Kryvyi Rih National University Vitaliya Matusevycha str., 11, Kryvyi Rih, Ukraine, 50027

\section{Introduction}

Arc short circuits arise in complete distributive devices because of electrical breakdown of isolation between phases or between phases and earth. The spark is a short-circuited breakdown, and the arc is a continuous isolation breakdown at which a load supports current of leakage. At the same time, temperature rises sharply; there is a sound shock wave, a light flash and electromagnetic radiation. A pillar of an electric arc can move along power lines at a speed up to $200 \mathrm{~m} / \mathrm{s}$, an amplitude of arc strength varies with a frequency of $100 \mathrm{~Hz}$ [1]. Arc circuits for up to $100 \mathrm{~ms}$ do not pose a high risk for equipment and personnel at $90 \%$, a discharge of $t<1 \mathrm{mc}$ does not represent a threat at all [2], but if discharge 
time increases, it can lead to considerable damage [3]. Burns from an electric arc caused 1,710 injuries according to the US statistics from 1992 to 2001 [4]. An arc-resistant wall between adjacent cells serves as passive arc protection used, but the mesh barrier of old cells will not provide necessary protection.

Possibility of acceleration of response of protection against arc circuit can significantly reduce a number of injuries from arc circuits in power supply systems. We determined factors that arise during the arc discharge and the possibility of using to accelerate response of protection against arc circuit in this study. This enables creation of a combined device for accurate determination of the location of an arc discharge. In particular, we will be able to extend a spectrum of sensitivity of an optical sensor by using ultraviolet radiation without its replacement.

\section{Literature review and problem statement}

Degradation of insulation is one of the most common reasons for failure of electrical components [5]. Experiments proved that a partial discharge is a reliable indicator. Its early diagnosis gives possibility to avoid a complete breakdown of an affected component of a power supply system. Usual measurement systems of partial discharges have some difficulty in measuring, especially in online environments and in noisy environments [6].

Consequences of a breakdown of insulation are well known. The trend implies a transition from conventional stand-alone testing to online monitoring to forecast an isolation resource, which results in the inclusion of high-frequency noise in trapped signals [7].

However, statistics show that it is not always possible to prevent accidents at a stage of partial discharges. Partial discharges often pass into a stage of arc circuits with a complete blocking of isolation with the development of a process of degradation of insulation. At this stage, it is necessary to use sensors to detect an electrical isolation breakdown to prevent further development of an accident. A document [8] provides a technological review of arc protection in distributive devices with an air-insulator. It covers the entire range from design aspects of distributive devices to the ultra-quick removal of an arc. A work [9] presents an assessment of a risk of an arc discharge in an electricity distribution system, including generation sources (GS).

There are four groups of sensors used to detect an electrical isolation breakdown [1]:

1. Protections in a function of pressure. Valve protection with end switches on pressure relief valves. Membrane protection, pneumatic switch with membrane tubes. Both protections are simple and cheap but hermiticity of a cell is necessary. In addition, mechanical protective devices do not fix an arc itself, but effects that arose after emergence of an electric arc. The valve protection works reliably on the short-circuit current I $>3.5 \mathrm{kA}$ only.

2. Temperature protection. The disadvantage of protection is the need to position a sensor directly near arc discharge location, which necessitates installation of a large number of sensors in each cell.

3. An antenna sensor, which responds to ionization of air directly near a place of an arc discharge, is also not suitable for control of extended elements. There is a design of a grounded antenna sensor that pulls an arc plasma into itself [5].

4. Optical sensors. Separate photocells or circular lenses, they send a signal through optical fiber to a detector unit or an open fiber-optic sensor without isolation of a length of $30-60 \mathrm{~m}$, which covers the volume of several cells as a loop. The disadvantage of optical sensors is their false response to sunlight or to brilliance of an arc of an electric welding machine. Because there are many false responses of arc protection devices, additional relays of maximum current protection or error detectors on current transformers $1 \mathrm{~A} / 5 \mathrm{~A}$ block them [4]. We believe that minimum condition for occurrence of an unstable arc is a current of about $0.5 \mathrm{~A}$ and a voltage of $15-20 \mathrm{~V}$.

In addition to the above properties, sound, electromagnetic and gamma-radiation accompanies an arc discharge, and an explosion occurs at high discharge power.

We need to resolve the problem of acceleration of response of protection against an arc circuit. This is possible due to refusal of its blocking with relay circuits for maximum current protection and reducing of an influence of solar radiation on operation of PAC (protection against arc circuit).

The faster we detect and eliminate an arc, which arises in distributive devices, the less is a risk to receive a serious injury or death for personnel [10]. Other benefits of minimization of welding time include reducing of additional damage, reducing of downtime, and, consequently, reducing of requirements for individual protection means (IRM).

Typically, at registering of an arc discharge, photo thyristors record a narrow part of a visible optical spectrum at the infrared boundary. A time difference between moments of a light impulse coming to ends of a light guide determines location of an arc discharge. This causes low accuracy of determination of an arc discharge point.

A base of one of the new methods for detection of a fault type of an arc circuit in an AC electrical installation is a use of a single-phase active power filter (APF) [11]. The results obtained in this study show that it is possible to detect a series of arc disruptions using APF only by updating its digital control with a function of arc fail detection, instead of designing of a special arc failure detector ab origin.

Thus, we have to solve the problem of increasing of sensitivity of protection against arc circuit now. But it is possible by converting ultraviolet radiation into a visible part of the optical spectrum, which will make it possible to expand the spectrum of the optical sensor into the region of UV radiation and, accordingly, will increase its sensitivity.

\section{The aim and objectives of the study}

The objective of the study is to develop a combined optical sensor for arc protection, which means to determine a sound and optical spectrum radiated with arc discharges, which will enable to increase sensitivity of a device to protect against arc circuits.

We set the following tasks to achieve the objective:

- expansion of a sensitivity range of an optical sensor;

- development of a device for simultaneous measurement in ultraviolet, infrared and optical spectra;

- development of a device for a combined use of light and sound radiation of an arc discharge for determination of the place of appearance of an arc discharge. 


\section{Investigation of the optical spectrum of an arc discharge}

Chemical elements radiate a spectrum, which is characteristic for each individual element, at combustion. We can obtain these spectra by combustion in an acetylene-air flame, or in conjunction with an electric arc, or at interaction with an electric spark. Large atlases of arc and spark optical spectra present these data, which proved to be very useful for decoding results of the optical research of an electric arc. Table 1 shows spectral lines for several chemical elements that are capable of being exposed to an electric discharge at a substation or at a distribution point [12]. We choose the six most commonly used elements for a detailed analysis. They are aluminum, tungsten, iron, copper, nickel and lead. Table 1 shows that the bulk of ( 15 sensitive lines) has an ultraviolet portion of the spectrum with wavelengths $<380 \mathrm{~nm}$, while a visible part (a background) of radiation consists of numerous low-intensity lines, as well as radiation of flame combustion products up to $670 \mathrm{~nm}$. Fig. 1 shows total spectral characteristics. The spectrum of characteristics has an interval of $50-100 \mathrm{~nm}$, and the interval in the region of the maximum is $10-20 \mathrm{~nm}$. The analysis of the spectra showed that for quick detection of a spark discharge before it switches to an arc discharge it is necessary to choose an optical detector sensitive to ultraviolet radiation.

Existing arc circuit protection schemes have silicon photovoltaic cells. This is because the maximum of their differential characteristic falls on the maximum radiation of a flame of an electric arc in the region (0.7-1.1) nm. Basically, these are receivers with an internal amplification of the photocurrent: avalanche photodiodes, phototransistors, field phototransistors and photo thyristors, which became widely used in arc circuit protection schemes.

It is convenient to investigate an arc discharge electric welding machines. There are three spectra of ultraviolet radiation: UV-A (315-400) nm, UV-B (280-315) nm, UV-C (200-280) $\mathrm{nm}$. At the same time, the most rigid is UV-C, which has an intensity of radiation up to $5 \mathrm{~W} / \mathrm{m}^{2}$ at a current of $200 \mathrm{~A}$, which is harmful to a person at a distance larger than 60 meters [13]. The welding arc discharge spectrum consists of $70 \%$ ultraviolet, $15 \%$ visible and $15 \%$ infrared radiation.

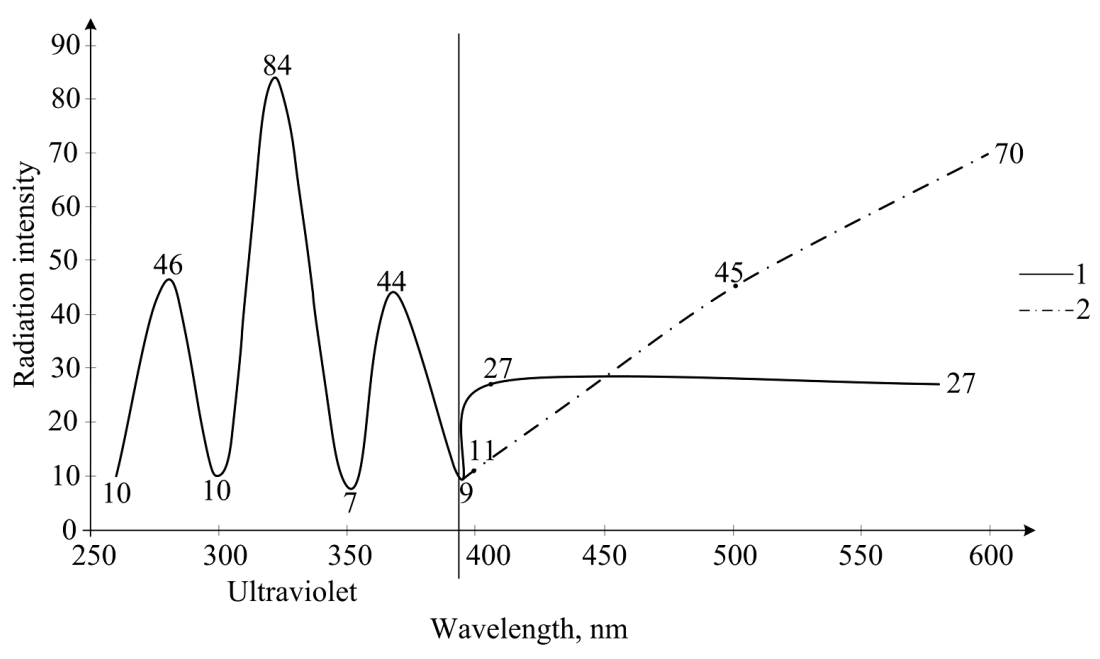

Fig. 1. Total spectral characteristics: 1 - spark and arc spectra of radiation of selected metals; 2 - spectral characteristic of relative sensitivity of a silicon photocell
Table 1

Wavelengths of radiation of arc and spark spectra of individual chemical elements [12]

\begin{tabular}{|c|c|c|c|c|}
\hline \multirow{2}{*}{$\begin{array}{c}\text { Chemical } \\
\text { element }\end{array}$} & \multicolumn{2}{|c|}{ Number of lines } & \multirow{2}{*}{$\begin{array}{l}\text { Sensitive } \\
\text { lines, } \mathrm{nm}\end{array}$} & \multirow{2}{*}{ Intensity } \\
\hline & Arc & Spark & & \\
\hline \multirow{4}{*}{ Aluminum - Al } & \multirow{4}{*}{23} & \multirow{4}{*}{19} & 308.2 & 8 \\
\hline & & & 309.2 & 9 \\
\hline & & & 394.4 & 9 \\
\hline & & & 396.1 & 10 \\
\hline Hydrogen $-\mathrm{H}_{2}$ & - & 1 & 656.2 & $\begin{array}{l}(2,000)- \\
\text { Spark }\end{array}$ \\
\hline \multirow{4}{*}{ Tungsten -W } & \multirow{4}{*}{34} & \multirow{4}{*}{49} & 289.6 & 7 \\
\hline & & & 294.4 & 7 \\
\hline & & & 291.6 & 7 \\
\hline & & & 400.8 & 6 \\
\hline \multirow{5}{*}{ Iron - Fe } & \multirow{5}{*}{15} & \multirow{5}{*}{10} & 259.9 & 10 \\
\hline & & & 302.0 & 9 \\
\hline & & & 358.1 & 9 \\
\hline & & & 371.9 & 9 \\
\hline & & & 385.9 & 10 - flame \\
\hline \multirow{2}{*}{ Copper - $\mathrm{Cu}$} & \multirow{2}{*}{74} & \multirow{2}{*}{68} & 324.7 & $>10$ \\
\hline & & & 327.3 & $>10$ \\
\hline \multirow{3}{*}{ Nickel - Ni } & \multirow{3}{*}{73} & \multirow{3}{*}{57} & 341.4 & 9 \\
\hline & & & 349.2 & 7 \\
\hline & & & 352.4 & 9 \\
\hline \multirow{5}{*}{ Tin - Sn } & \multirow{5}{*}{45} & \multirow{5}{*}{45} & 283.9 & 10 \\
\hline & & & 300.9 & 10 \\
\hline & & & 303.4 & 10 \\
\hline & & & 317.5 & 10 \\
\hline & & & 326.2 & 9 \\
\hline \multirow{3}{*}{ Lead - Pb } & \multirow{3}{*}{39} & \multirow{3}{*}{39} & 280.2 & 8 \\
\hline & & & 283.3 & 8 \\
\hline & & & 405.7 & 8 \\
\hline Carbon $-\mathrm{C}$ & 1 & 12 & 247.8 & 400 \\
\hline
\end{tabular}

The UV-C spectrum with a wavelength below $280 \mathrm{~nm}$ is absent in solar radiation on the Earth's surface [14]. Because the fact that the ozone layer absorbs this part of the spectrum completely and does not reach the surface of the Earth. There are wide-band materials based on gallium phosphide, nitrides of gallium and aluminum, flint carbide and diamond used for sensors of "hard" UV radiation. But mentioned devices are not widespread in the real cells or distribution points due to their high cost and insufficient information in technical literature. There--2 fore, we choose photochromic materials, crystallophosphors or fluorescent dyes for transition of non-visible ultraviolet radiation into the region of the visible optical spectrum. Typically, spectral shifts lie between an ultraviolet part and visible parts of the spectrum. The higher the power of radiation, the faster an output photoform will pass from an ultraviolet part to a visible part of the optical spectrum.

We chose photo thyristors TF 132 25-10 type for further research, which are used in protection schemes against 
arc circuits for more than 20 years. Time of protection response is $10^{-5} \mathrm{sec}$. Nominal current is $25 \mathrm{~A}$, voltage is $1,000 \mathrm{~V}$. Power of a controlling light flow is from 1.0 to 1,000 MW.

Photo thyristors have a number of advantages over other semiconductor optical sensors, such as high load capacity at low power of a control signal, ability to memorize after removal of a control signal, high speed, and high sensitivity.

We selected the incandescent lamp BK 215-225-60 type with a voltage of $220 \mathrm{~V}$ and a power of $60 \mathrm{~W}$ with a light flow of $750 \mathrm{~lm}$ to record characteristics of a photo thyristor in a visible and infrared spectrum. A manufacturer recommends a similar lamp to control response of photo thyristors on a light signal. A photo thyristor starts operation from the light of a 60 -watt lamp at a distance of $10 \mathrm{~cm}$ when powered by 12 Volts of direct current.

We used a red fluorophore dye to convert ultraviolet radiation of an arc discharge into a spectrum to which a sensitive photo thyristor is sensitive. We chose a mercury lamp with a bulb with UFS-3 light filter as a source of ultraviolet radiation. The resonance line of mercury has a wavelength of $253 \mathrm{~nm}$. Luminophore covered the body of the lamp from the inside. It emits waves of (300400) $\mathrm{nm}$ with a maximum of $350 \mathrm{~nm}$. Fig. 2 shows excitation of the spectrum of fluorophore.

Fig. 3 shows location of devices during recoding of photo thyristor light characteristics

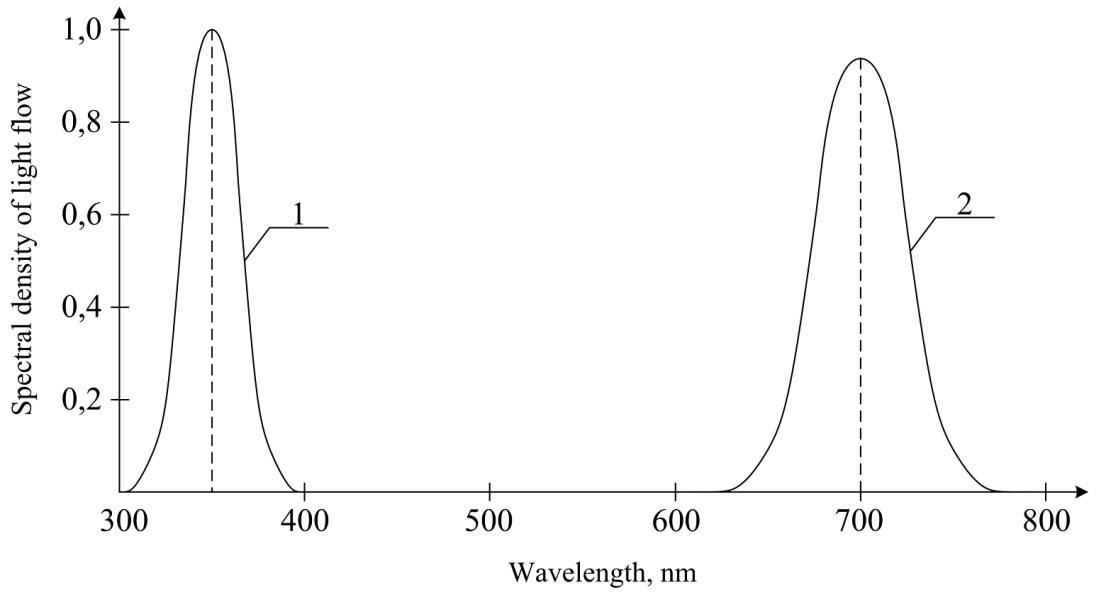

Fig. 2. Dependence of intensity of radiation on a wavelength: $1-$ spectrum of mercury lamp; 2 - spectrum of radiation of fluorophore

Curve on Fig. 4 illustrates characteristics of the control of photo thyristor: from the threshold minimum of insensitivity to lighting to the minimum threshold resistance of the photo thyristor switching on. The control area is between the curve and the coordinate axes. The greater illumination of a light input of the photo thyristor, the less its resistance: switching on current remains constant, and the voltage decreases to almost zero. A light flow from fluorophore causes an additional reduction of internal electrical resistance, which increases sensitivity of the photo thyristor.

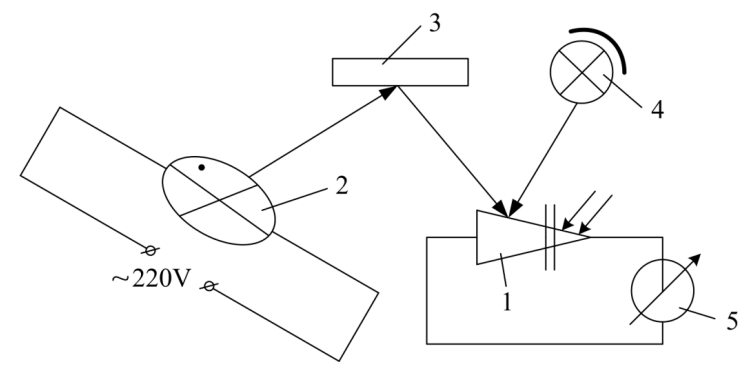

Fig. 3. Location of devices for recoding of light characteristics of a photo thyristor: 1 - photo thyristor; 2 - source of ultraviolet radiation; 3 - fluorophore; 4 - incandescent lamp; 5 - measuring equipment

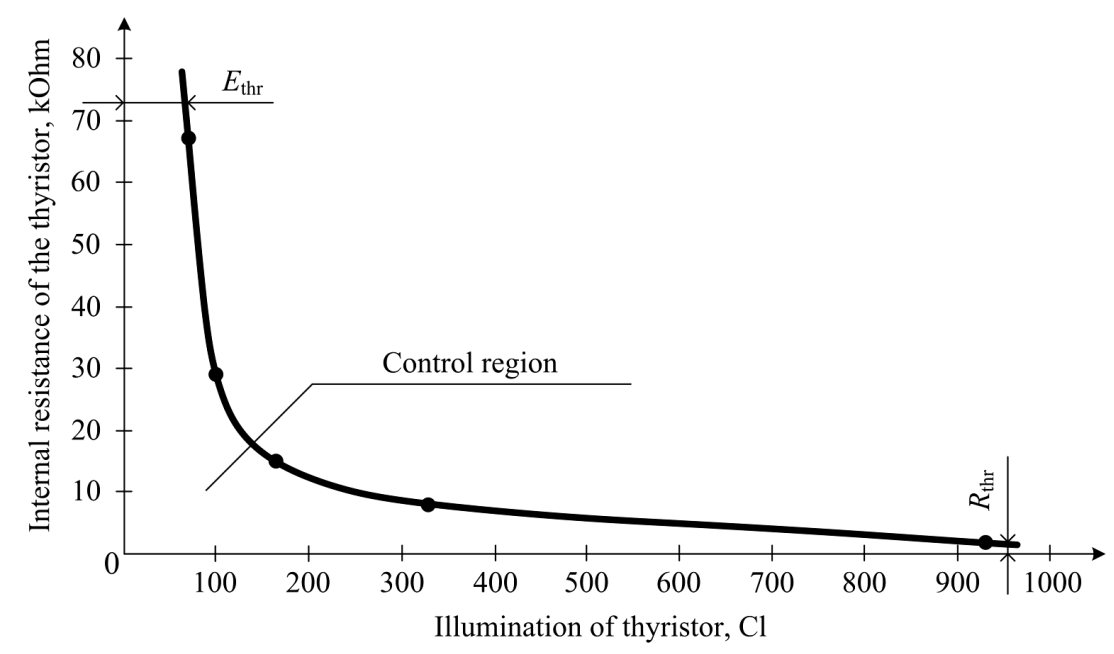

ig. 4. Dependence of internal electrical resistance of the photo thyristor on a magnitude of a light flow, where $E_{\text {thr }}$ is a threshold of illumination, $\mathrm{Cl}$; $\mathrm{R}_{\mathrm{thr}}$ - internal threshold resistance of the thyristor, $\mathrm{kOm}$

We can determine a light flow emitted by fluorophore under the action of ultraviolet radiation by the expression

$$
\Phi_{e l}=\int_{\lambda_{1}}^{\lambda_{n}} \phi_{r}(\lambda) \cdot \alpha(\lambda) \cdot \eta_{a}(\lambda) \cdot d \lambda,
$$

where $\varphi_{r}(\lambda)$ is the function of spectral density of the flow of fluorophore excitation; $\alpha(\lambda)$ are the spectral values of an absorption coefficient of fluorophore; $\eta_{a}(\lambda)$ are the spectral values of an energy output of fluorophore; $\lambda_{1}$ and $\lambda_{n}$ are the limits of the spectrum of excitation.

We can see from formula (1) that the light flow of fluorophore is a function of spectral density of an excitation flow from a source of ultraviolet radiation. The formula provides an opportunity to determine a light flow from a specific fluorescent surface, depending on efficiency of converting the ultraviolet radiation of an arc discharge into a visible part of the optical spectrum.

\section{Investigation of the electromagnetic spectrum of arc discharge radiation}

Transient processes, impulse overvoltage, current throttles accompany an arc discharge. A prerequisite for 
formation of powerful electromagnetic waves is a sufficiently high frequency of electrical oscillations. Necessary much higher frequencies than $50 \mathrm{~Hz}$ of industrial frequency. The electromagnetic spectrum of an electric welding arc has three resonance bands; their centers are at a frequency of $750 \mathrm{kHz}, 3 \mathrm{MHz}$, and $20 \mathrm{MHz}$ [13, 14]. Absorbing pincers and vertically polarized antennas are used at a height of $3 \mathrm{~m}$ and at a distance of up to $10 \mathrm{~m}$ (GOST 11001-69) to control interferences of arc discharge for radio communications. Measuring takes place at a distance of $20 \mathrm{~m}$ from the extreme wire on air lines. Electromagnetic radiation of a corona discharge of an air line is $0.154-100 \mathrm{MHz}$. We should note that its own resonance frequency of an oscillatory circuit depends on a magnitude of its reactive resistance and can reach 5$100 \mathrm{kHz}$. We can calculate a period of resonant frequency of a power line by the formula

$$
T=2 \pi \sqrt{L \cdot C}, \mathrm{~s},
$$

where $L$ is the inductance in $\mathrm{H}$, and $C$ is the capacitance in $\mu \mathrm{F}$.

Based on the analysis of given data we can conclude that the electromagnetic spectrum of an arc discharge is not suitable for diagnostics of an arc discharge at high frequencies because it is impossible to determine precisely a place where an arc discharge occurs. However, we can control it at low frequencies, when the power of an electric arc changes with doubling frequency of the supply voltage $(100 \mathrm{~Hz})$, and the electromagnetic field is more local in nature.

The disadvantage of the method is that the electromagnetic field of each power supply depends on load capacity of surrounding transformers, tires, and adjacent cell lines. We used a wavelength meter of a bridge type to determine electromagnetic parameters of an arc discharge. Fig. 5 shows its functional diagram.

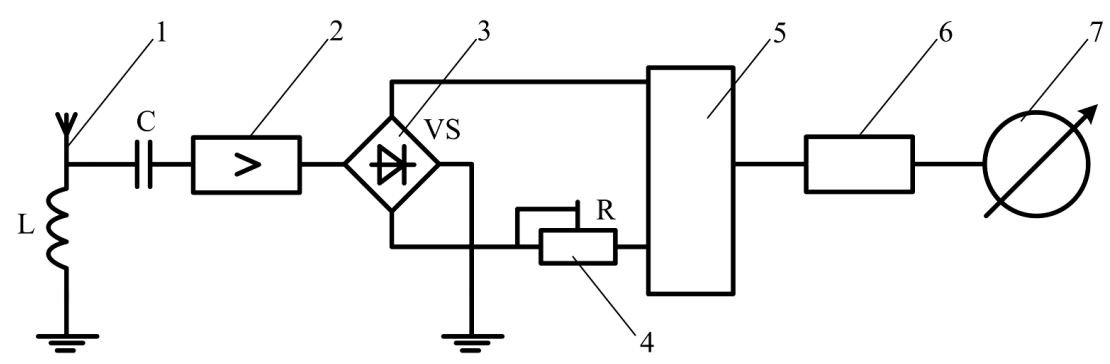

Fig. 5. Functional diagram of a wavelength meter

The wavelength meter consists of ultra-high frequency antenna 1 , which is connected to diode bridge 3 via aperiodic amplifier 2, one of which has amplitude detector 5 connected to the output at which galvanometer 7 is connected through repeater 6 . Before starting measurements, the wavelength is set to zero using potentiometer 4 .

We used arc discharges of a welding transformer (voltage $60 \mathrm{~V}$, current $100 \mathrm{~A}$ ), electrical lighters for gas appliances, a high-voltage battery (voltage 4,500 V), and a pulsed photoluminescope (power $100 \mathrm{~W}$ ) as arrays of electromagnetic radiation. We determined that intensity of electromagnetic radiation of an arc discharge is directly proportional to the power of a radiation source.

\section{Investigation of the sound spectrum of arc discharge radiation}

A level of arc discharge sound pressure can reach more than $140 \mathrm{~dB}$. Electrical spark discharges, which are accompanied by hiss, are a manifestation of waves of the ultrasound range. Ultrasonic waves are very similar to sound ones and differ from them only by frequency because they occupy a frequency range above $20 \mathrm{kHz}$. Discharge activity of ultrasonic oscillations is particularly manifested in the frequency range (37-43) $\mathrm{kHz}$ at wavelength (100-400) $\mathrm{nm}$. For measurements, piezoelectric structures, which have the required resonant frequency in the range of ultrasound, are used [14]. The advantage of ultrasound is a greater direction of radiation than in sound, which has properties close to light radiation. If we know velocity of light and sound waves, measurement of a time difference gives possibility to calculate a distance to an electric arc that caused their appearance accurately.

Microphones are the most commonly used devices that convert sound into an electrical signal: electrodynamic, tape, condenser and electromagnetic ones. For acoustic measurements, the most suitable is MK-6 non-directional condenser microphone: frequency $40,000 \mathrm{~Hz}$, sound pressure level $9 \mathrm{~dB}$. According to the National Standard of the Russian Federation GOST R55191-2012 (IEC 60270: 2000) High voltage test methods: "Partial discharge measurements: we cannot use acoustic and optical methods to determine quantitative characteristics of partial discharges: only to determine location of partial discharges. An arc discharge can emit sound with the frequency of industrial electric current. " In comparison, in Ukraine there is an intergovernmental standard "Electrical equipment and electrical installations of the voltage of $3 \mathrm{kV}$ and above. General methods for testing of electrical strength of insulation ", which started its action as a state standard of Ukraine by the order of the State Standard of Ukraine of June 18, 1999, No. 354 as of 01.01.2000. This standard establishes general methods for testing of isolation of electric equipment by the voltage of lightning and switching impulses, shortterm alternating voltage, constant voltage, conditions for conduction of these tests and requirements for an object of the test, as well as recommendations for the evaluation of test results.

Work [15] considers determination of location of an arc discharge by comparison of intensity of a signal from a flash on both ends of a ten-meter light conductor. The maximum time difference between arrivals of signals from the point of flash to sensors at the ends of the lightning conductor is $5 \mathrm{~ns}$. This is a very low temporal level compared to the light conductor of a light velocity of $300,000 \mathrm{~km} / \mathrm{s}$. In contrast to this, the system proposed here has the feature that velocity of sound, which reaches $342 \mathrm{~m} / \mathrm{sec}$, determines arc discharge location, which simplifies a device for measurement of time and determination of the damaged cell greatly.

We install a relay for arc protection in a cell, which contains a tire system A, an electric cable of "l" length, a high-voltage switch Q, which is disconnected by YAT electromagnet. PAC consists of a piezoelectric ultrasound sensor US, a flash sensor in the form of several photo thyristors PT, 
a timer T, a logic element "I". The US sensor is mounted in a focal cone under the cell's ceiling. Optical input of photo thyristors can be connected to open optical light conductors.

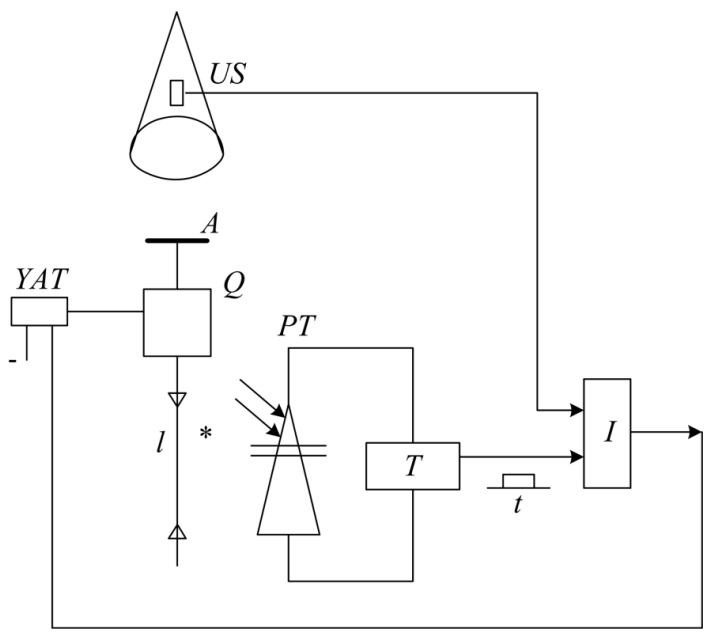

Fig. 6. System for determination of location of an arc discharge: $A$ - tire system; $Q$, YAT - high-voltage switch with a disconnecting electromagnet; / - power cable;

PT - photo thyristor; $T$ - timer; I- logic element,

US - ultrasound sensor; $t$ - impulse length of a timer

The device works as follows: we set an impulse length $[t]$ to the timer $T$. The length is equal to the time necessary for ultrasound to reach US sensor from the bottom of the cell, the output of which is connected to the input of the logical element "I".

In the case of an electric discharge appearance in the middle of the cell, the signal from flash sensors PT enters the timer $T$ input, which outputs a signal by length " $t$ ". If the signal from the acoustic sensor US enters the logic element "I" at the same time as the " $t$ " signal, then the system triggers and disconnects the high-voltage switch $Q$ via its YAT electromagnet. If the signal from the acoustic US sensor arrives at the end of the timer signal " $t$ ", then the system does not react to it because it is a sound signal from a third party object. The system will not respond to sunlight and an electric arc of a welding machine because their appearance is not accompanied by a synchronous ultrasonic signal at a frequency of $20-50 \mathrm{kHz}$.

\section{Investigation of radioactive radiation of an arc discharge}

We know that gamma quanta appear as a result of corona discharges and arc discharges. The basic sanitary rules of Ukraine allocate a whole class of radio-electric devices with unused X-rays. This class includes welding, melting, zone cleaning materials, electronic microscopes, and others. We expect an output of X-rays at a voltage of $10 \mathrm{kV}$ or more. Table 2 shows the dependence of the power of the exposure dose on supply voltage.

We tested the arc of a 150-ampere welding device was for gamma-quantum radiation using a dose-radiometer of MKS-03D «Strizh» type (factory number of the device 27). In the range of $0.1 \mu \mathrm{Sv} / \mathrm{h}$ to $0.1 \mathrm{~Sv} / \mathrm{h}$, determination error of the dose does not exceed $15 \%$. Dosimetric control did not detect a significant deviation of gamma radiation of the welding arc from background radiation. We obtained data using the specified device.

Table 2

Dependence of the power of the exposure dose on supply voltage

\begin{tabular}{|c|c|c|c|c|}
\hline Voltage, $\mathrm{kW}$ & $10-30$ & $30-50$ & $50-100$ & $100-150$ \\
\hline $\begin{array}{c}\text { Power of exposure dose, } \\
\mu \mathrm{R} / \mathrm{s}\end{array}$ & $3-3 \cdot 10^{2}$ & $30 \cdot 10^{2}$ & $3 \cdot 10^{3}$ & $10^{5}$ \\
\hline
\end{tabular}

8. Discussion of the results of investigation of the spectrum of radiation of arc circuits

Investigation of the optical spectrum of radiation of metals under the action of an arc discharge showed that $70 \%$ of the radiation falls on the ultraviolet part and $15 \%$ on the visible and infrared parts of the spectrum [14]. Arc protection sensors are made based on silicon semiconductors that do not react to ultraviolet light because their maximum sensitivity is in the infrared zone and in the visible optical spectrum [16]. We used fluorescent dye to convert ultraviolet radiation into the spectrum of visible arc protection sensors, which, under the action of UV radiation, glowed in red light. We used an electric lamp as an UV source. Radiation of fluorophore under its action increased a signal at the output of the photo thyristor by $15 \%$. We can explain low efficiency of the proposed method by the fact that the power of the ultraviolet lamp was 10 times less than the power of the incandescent control lamp.

The author's development differs by the method for determination of contribution of converted ultraviolet radiation to the visible part of the spectrum, which gives an additional reduction of internal resistance of the photo thyristor and, accordingly, increases its sensitivity when we introduce a fluorescence screen. Authors of works [14] and [16] developed ultraviolet sensors that do not react to the visible part of the spectrum.

Investigation of the sound spectrum of an arc discharge.

Propagation of sound oscillations is in the inverse quadratic dependence of wave frequency. Ultrasound has a property of direction. Based on these two parameters, we used ultrasound to localize location of an electric discharge. When we know velocity of sound and light, it is quite easy to determine a distance to an arc discharge location by the difference in time of receipt of these two signals. Fig. 6 presents a functional diagram for detection of a single cell, where an arc discharge appears. The mentioned features of the scheme simplify the device for measurement of time to determine short-circuit location and increase accuracy of measurement of time by three orders $\left(10^{3}\right)$.

Investigation of radioactive radiation of an arc discharge.

We know that gamma-quantum appear due to corona and arc discharges, as well as at operation of powerful welding machines. Gamma radiation of powerful electrical installations becomes noticeable at a voltage over $10 \mathrm{kV}$. Uneven scattering of gamma quanta-quantum, in dependence on the location geometry of equipment and an effective atomic number of scattering surfaces, makes difficult to use gamma radiation to determine location of an arc discharge. In addition, it is necessary to take into account complexity of equipment, its dependence on vibration, an influence of atmospheric conditions and the electromagnetic field. 
We proposed the solution of the problem of increasing of sensitivity of protection against arc circuit. This is possible by converting the ultraviolet radiation into the visible part of the optical spectrum, which will expand the spectrum of sensitivity of the optical sensor to the region of ultraviolet radiation and, accordingly, will increase its sensitivity. This is because of the fact that $70 \%$ of radiation of an arc discharge falls on the region of ultraviolet radiation and only $15 \%$ on the visible and infrared spectra of optical radiation.

The disadvantage of the development is a lack of tests on real power supply lines at high arc discharges. Lack of substantiation for choice of fluorophore: in terms of maximum light output. We did not select location of the photo sensor in cells, but there are works, which elaborate this issue [17]. In the future, it is necessary to use devices that control the state of electric isolation under voltage, which greatly reduces possibility of arc discharges [18].

\section{Conclusions}

1. We developed the method of expansion of the optical range of sensitivity of photo sensors by means of registra- tion of an additional light flow from fluorophore, which causes additional reduction of internal electrical resistance and promotes increase of sensitivity of photo thyristor. We determined the necessary optical range of photosensitivity of photosensors and proved possibility of its expansion in the UV range. We obtained a characteristic of a photo thyristor control: from the threshold minimum of insensitivity to illumination to the minimum threshold resistance of the switching on the photo thyristor. The greater illumination of the light input of the photo thyristor, the less its resistance: switching on current remains constant, and the switching on voltage decreases to almost zero.

2. We developed a device for simultaneous control of transformed ultraviolet, visible, and infrared optical radiation by one sensor. We used a screen covered with fluorophore to convert UV radiation of an arc discharge to the spectrum, to which the photo thyristor is sensitive.

3. We developed a device with combined use of light and sound radiation of an arc discharge. It uses the velocity of sound, which is three orders of magnitude less than the velocity of light, to determine location of an arc discharge, which simplifies a device for time measurement and determination of location of short circuit greatly.

\section{References}

1. Broadcom Limited. Optical sensors for arc protection systems of complete switchgears // Energetik. 2007. Issue 1. P. 31-33.

2. The main advantages and operational capabilities of fiber-optic arc protectors // Information and Control Systems. 2012. Issue 4 (40). P. 26-32.

3. Mudrick R., Pasko A. High-speed protection arcs in closed switchgear 6 (10) kV // Electrical networks and systems. 2011. Issue 5. P. 34-45.

4. Efficiency of arc protection Arched AQ 100 // Chief energetic. 2014. Issue 4. P. 13-20.

5. Electromagnetic sensing for predictive diagnostics of electrical insulation defects in MV power lines / Shafiq M., Hussain G. A., Kütt L., Lehtonen M. // Measurement. 2015. Vol. 73. P. 480-493. doi: 10.1016/j.measurement.2015.05.040

6. Allahbakhshi M., Akbari A. A method for discriminating original pulses in online partial discharge measurement // Measurement. 2011. Vol. 44, Issue 1. P. 148-158. doi: 10.1016/j.measurement.2010.09.036

7. Performance evaluation of noise reduction method during on-line monitoring of MV switchgear for PD measurements by non-intrusive sensors / Hussain G. A., Shafiq M., Kumpulainen L., Mahmood F., Lehtonen M. // International Journal of Electrical Power \& Energy Systems. 2015. Vol. 64. P. 596-607. doi: 10.1016/j.ijepes.2014.07.057

8. Aspects of arc-flash protection and prediction / Kumpulainen L., Hussain G. A., Rival M., Lehtonen M., Kauhaniemi K. // Electric Power Systems Research. 2014. Vol. 116. P. 77-86. doi: 10.1016/j.epsr.2014.05.011

9. Arc Flash Hazard in Distribution System with Distributed Generation / Kanokbannakorn W., Hongesombut K., Teerakawanich N., Srisonphan S. // Procedia Computer Science. 2016. Vol. 86. P. 377-380. doi: 10.1016/j.procs.2016.05.106

10. Arc flash - Safety at the speed of light. URL: https://www.electricalreview.co.uk/features/7650Arc_flash_-_Safety_at_the_speed_ of_light.html/

11. Shunt active power filter-based approach for arc fault detection / Jovanovic S., Chahid A., Lezama J., Schweitzer P. // Electric Power Systems Research. 2016. Vol. 141. P. 11-21. doi: 10.1016/j.epsr.2016.07.011

12. Rusinov A., Ilyasova N. Atlas of fiery, arc and spark spectra of elements. Moscow: Gosgeoltekhizdat, 1958. 120 p.

13. Levchenko O., Malakhov A., Arlamov Y. Ultraviolet radiation in manual arc welding of coated electrodes // Automatic welding. 2014. Issue 6-7. P. 155-158.

14. Lazorenko Ya. P., Shapovalov E. V., Kolyada V. A. Analysis of the arc welding radiation spectrum for monitoring arc welding // Automatic welding. 2011. Issue 11 (703). P. 24-27.

15. Fiber-optic arc flash sensor based on plastic optical fibers for simultaneous measurements of arc flash event position / Jeong H., Kim Y., Kim Y. H., Rho B. S., Kim M. J. // Optical Engineering. 2017. Vol. 56, Issue 2. P. 027103. doi: 10.1117/1.oe.56.2.027103

16. Vechkanov A. V., Mayorov M. I., Nikishin E. V. Solar-blind ultraviolet sensors based on a GAP-diode and a phosphor // The successes of modern science and education. 2016. Vol. 5, Issue 12. P. 85-89.

17. Arc protection of 6-10 kV switchgear with longitudinal-lateral inclusion of optical sensors // Electrotechnical Internet portal. URL: https://www.elec.ru/articles/dugovye-zaschity-kru-6-10-kv-s-prodolno-poperechny/

18. Bogatyrev Yu. L. Monitoring and diagnosing the technical condition of insulation of air and cable lines under operating voltage // Electric networks and systems. 2011. Issue 4. P. 39-42. 